Mariam V. Aghababyan

\title{
Redeeming Phelypaea armena from oblivion, with a reassessment of Transcaucasian Cistanche (Orobanchaceae)*
}

\begin{abstract}
Aghababyan, M. V.: Redeeming Phelypaea armena from oblivion, with a reassessment of Transcaucasian Cistanche (Orobanchaceae). - Fl. Medit. 23: 131-139. 2013. — ISSN: 11204052 printed, 2240-4538 online.

Four Cistanche species are reported from Transcaucasia in the literature: C. flava, C. salsa, C. ambigua, and C. fissa. The first and last of them are undoubted members of the region's flora, but the occurrence of the other two is at best unconfirmed. Conversely, two additional species are here recorded: C. armena, formerly confused with the quite different C. salsa, and C. ridgewayana, which had on occasion been misidentified as $C$. ambigua. Together with $C$. fissa, the two newly recorded species are growing in a smallish area in the Arax River valley, on the border between Armenia and Nahičevan, and should be looked for on the opposite side of the Arax, on Turkish territory, from where none is known so far. Cistanche armena is a new combination, validated here.

Key words: Broomrape family, Caucasia, new combination, Karl Koch.
\end{abstract}

\section{Introduction}

Cistanche, a member of the Orobanchaceae family, is less diverse than Orobanche but of similar complexity. It is widespread in the Palaeotropical and -subtropical regions of the Northern Hemisphere, but its perhaps 20 species are of patchy occurrence, being narrowly specialised ecologically: they grow on sandy saline soils with high water deficit in desert, semi-desert and steppe vegetation; and as far as is known, they parasitise a limited range of hosts with similar preferences.

The genus has not been revised in its entirety since Beck's (1930) family monograph. In the Mediterranean area (Greuter \& al. 1989) it is represented by 5 species, 4 of which grow in N. Africa but only one is found in Anatolia (Gilli 1982). For the Iranian region (Schiman-Czeika 1964; Gilli 1979; Saeidi Mehrvarz \& Shahi Shavvon 2008) no less than 8 species are recorded, and 7 for the entire former Soviet Union (Novopokrovskij 1958).

In the Caucasus region Cistanche is confined to the lowlands of Transcaucasia, from which area 4 species were reported by Novopokrovskij (1958): Cistanche flava (C. A. Mey.) Korsh., C. salsa (C. A. Mey.) G. Beck, C. ambigua (Bunge) G. Beck, and C. fissa 
(C. A. Mey.) G. Beck; of which Grossgejm $(1934,1949)$ knew only 3 (not C. ambigua). (The most recent, patchy account, Domina \& Raab-Straube 2010, treats C. ambigua as a synonym of $C$. salsa and forgets $C$. flava altogether.) Country-wise, the current distribution record is: 2 species in south-easternmost Georgia, C. salsa and C. fissa (Mchvetadze 1999); 3 in Azerbaijan, all except C. ambigua (Karjagin 1957); and 3 both in Nahičevan and Armenia, all except C. flava (Karjagin 1957; Caturjan 1987). In Armenia, the known localities of the three species on record are all situated in the Arax valley, in the Erevan Province, close to the border with Nahičevan and Turkey.

During my prospection of the said area, I collected a Cistanche that did not appear to belong to any of the species that had been mentioned for Armenia and Nahičevan. I further realised that Karl Koch, during his trips of 1836-1837 to Caucasia, had visited that same region and had collected Cistanche material that he described and named as Phelypaea armena (Koch 1843). Koch's name had been synonymised with Phelypaea salsa C. A. Mey. by Boissier (1879) and, under the authority of the monographer Beck, was consistently included in $C$. salsa in all subsequent works dealing with the Transcaucasian flora.

The scope of the present study is to examine the Cistanche material I had collected in view of its possible identity of with Phelypaea armena K. Koch and to establish its relation with the other Cistanche species that have been cited for the area. In so doing, I shall also comment on other Transcaucasian reports of representatives of that genus.

\section{Material}

Specimens collected by me have been deposited at ERE, with duplicates at PAL-Gr, and are documented by colour photographs as well. In addition, relevant material (as cited below) in the herbaria ERCB, ERE, and LE has been studied, and dozens of colour photographs of Cistanche salsa, taken in the wild in Israel, Jordan, Egypt, Tajikistan and Kazakhstan, have been viewed on the Internet.

\section{Results}

Koch (1843) described Phelypaea armena in the following terms (translated from the original Latin): "Unbranched, glabrous below, covered with fleshy, coloured, ovate, acute scale leaves, above with white-woolly ovate-lanceolate bracts and linearlanceolate bracteoles; calyx half as long as the bracts and one-third as long as the corolla, with ovate, acute, unequal lobes; corolla straight, with almost equal lobes, inside beset with a broad ring of white hairs from which the stamens arise; seeds naked. Abounds in the plain along the Araxes river."

This description is vague enough to explain the subsequent universally accepted synonymisation of Koch's species with the widespread Cistanche salsa (and, besides, it might well apply to some other species as well). Without study of Koch's original material, it is not possible to decide confidently which species he had before him. Koch's own herbarium fell victim to the destruction of the Berlin-Dahlem Herbarium by war 
action in 1943, when only few types, none of Orobanchaceae, survived. I was however fortunate to locate a duplicate in the St. Petersburg Herbarium (LE), with the following label in Koch's own handwriting: "Phelypaeae salsae et fissae proxima, ut videtur nova. In salsis ad Araxem legit Dr Koch 1837” (Fig. 1). Below, I am designating this specimen as the lectotype for the name.

The classical area from which Phelypaea armena was described is part of the plain bordering the left side of the Araxes River, opposite to Mt. Ararat which rises on the right side, on Turkish territory. It ranges from the south-east of Erevan Province in Armenia to the adjoining north-western portion of Nahičevan, and consists of flat areas of sandy, saline soil which, unlike the surrounding fertile land, are unsuited for cultivation and are covered with natural salt-brush formations. From this restricted area, as stated above, no less than 3 Cistanche species have been recorded: C. salsa, C. fissa, and C. ambigua (Karjagin 1957, Caturjan 1987). The study of herbarium material and my own field work have confirmed that, indeed, 3 species exist in the area - but only one of those supposed to be there.

Cistanche fissa. - I have studied the following specimens collected in the area of study, in the Arax River valley (Armenian part only): v $5 \mathrm{~km}$ na sev.-vost. ot sel. Dašlu, 800-900 $\mathrm{m}$ nad u. m. frigana pologikh juznyh smytyh sklonah [5 km N-W of village Dašlu, 800900 a.s.1., low phrygana, south-facing eroded slopes], 25.5.1955, Aslanjan \& Karapetjan (ERE 58872, det. Cvelev); Vedinskij r-n, Arazdajan, zasolennye počvy [Vedi province, Arazdajan, salty soils], 28.5.1954, Barsegjan (ERE 29137).

Cistanche ridgewayana Aitch. \& Hemsl. - The following specimens from the Arax River valley, just outside of the Armenian border, were seen: Severo-zap. okr. Nahičevana, polupustynja [NW part of Nahičevan, semidesert], 24.5.1957, Gabrieljan \& Avetisjan (ERE 63588; det. Cvelev in 1957 as C. ambigua); same provenance and date, Gabrieljan (ERE 92676; det. Caturjan); same provenance and date, Gabrieljan \& Avetisjan (ERCB 8519; det. Caturjan).

Cistanche armena. - This appears to be the most frequent of the three, at least in the Armenian portion of the study area, judging from my observations in the field and the collections at hand (all from Armenia): Ju.-v. okr. Arazdajana, na puhlyh solončakah, na Statice mejerii [SE of Arazdajan, on salty soil, on Statice meyeri], 9.6.1959, Gabrielian (ERE 92673; det. Caturjan as C. salsa); Okr. Arazdajana, na puhlyh solončakah [near Arazdajan, on salty soil], 9.6.1959, Gabrieljan, (ERE 92674; det. Caturjan as C. salsa); Ju.-v. okr. Arazdajana, na puhlyh solončakah [SE of Arazdajan, on salty soil], 9.6.1959, Gabrieljan (ERE 92675, mounted with a sterile shoot of Limonium meyeri (Boiss.) Kuntze; det. Caturjan as C. salsa); Ararat distr., near Surenavan, "solonchaki" (salt body), parasitizing Halostachys belangeriana (Moq.) Botsch. (det. Akopyan), 3947'30”N, 444'48'E, alt. 800 m, 3.7.2008, Gabrieljan \& Aghababyan (ERE, PAL-Gr 48159); Araratskij r-n, okr. Hor-Virapa, vozle polja [Ararat distr., near Hor-Virap, by a field], 9.5.2010, Tamanjan \& Fajvush (ERE 182237; det. Tamanjan as C. salsa); Ararat distr., Hor-Virap monastery, near cemetery, old irrigation channel, salty soil, parasitizing Salsola dendroides Pall. (det. Akopyan), 3953'02'N, 44³4'51'E, alt. 819 m, 21.5.2010, Gabrieljan \& Aghababyan (ERE, PAL-Gr 58750).

A study of this plentiful material showed that it is quite distinct from Cistanche salsafor which it had generally been mistaken - but coincides exactly with the original specimen of Koch's Phelypaea armena. The drawing of "C. salsa” in Flora Armenii (Caturjan 


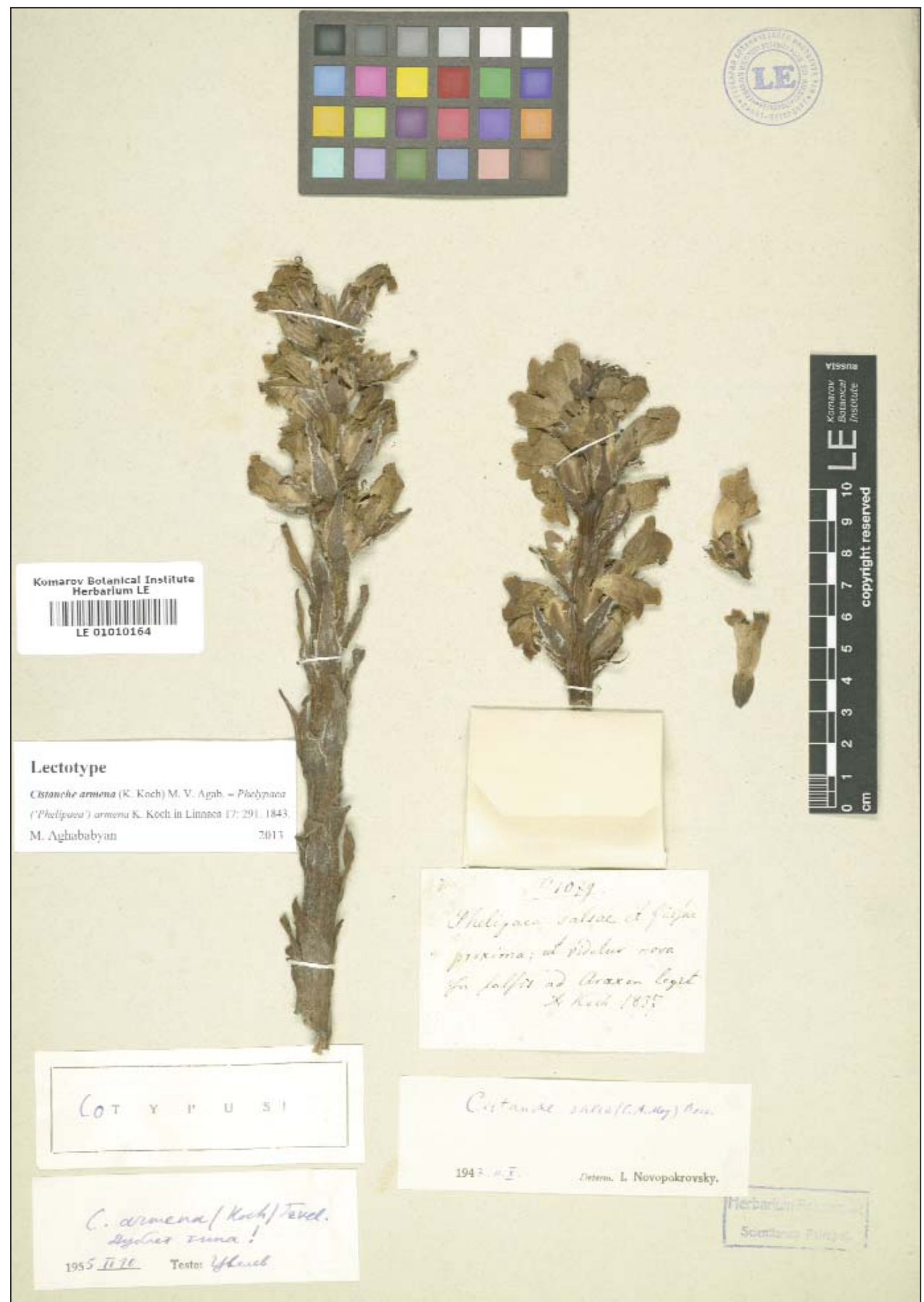

Fig. 1. Lectotype of Cistanche armena (K. Koch) M. V. Agab. (published by kind permission of the Herbarium, Komarov Botanical Institute, St. Petersburg). 
1987: pl. 154) is in fact an excellent likeness of that same species. To the best of my knowledge, Cistanche salsa proper has never been found in Armenia, nor is it likely to grow in nearby Nahičevan.

A comparison of colour photographs of the live plants (Fig. $2 \& 4$ vs. 3) shows the essential differences. In Cistanche salsa the inflorescence is and remains very compact, consisting of closely packed flowers that completely hide the inflorescence axis; the corolla tube is completely white, curved outward only near its tip; the lobes are wider than long, almost semicircular, flat and initially patent but soon rolling back, and with their dark purple colour offer a sharp contrast against the tube; finally, the two longitudinal folds of the lower lip, in the throat, are high, end in a tooth-like projection and are bright yellow to almost orange (judging from the numerous good colour photographs from all over the species range that are available on the Internet, these features are remarkably constant and scarcely vary). In the Armenian species, in contrast, the inflorescence is lax and elongated, with irregularly scattered, often subverticillate flowers, so that the strongly ridged and grooved inflorescence axis can be seen (a feature that is easily observed on dry material, too); the corolla tube is curved outward for most of its length, and in its distal half passes from white to reddish violet, the very colour of the lobes; these lobes are suborbicular in shape, as long as wide, and remain somewhat concave (spoon-shaped) throughout the anthesis, not rolling back; the two longitudinal folds, ventrally in the throat, are less prominent, lack a tooth-like projection distally, and are whitish without any yellow tinge.

In conclusion, Koch's Phelypaea armena is an excellent species of its own, quite distinct from Cistanche salsa with which it has so far been generally confused, and replacing it in, at least, Armenia and almost certainly Nahičevan. As in the genus Cistanche it still lacks a valid name, I am here proposing the necessary new combination:

Cistanche armena (K. Koch) M. V. Agab., comb. nov. $\equiv$ Phelypaea ('Phelipaea') armena K. Koch in Linnaea 17: 291. 1843. - Lectotype (designated here): In salsis ad Araxem, 1837, Koch (LE). - Fig. 1.

\section{Discussion and Conclusions}

The following three Cistanche species can be confirmed as occurring in the study area, and therefore in Transcaucasia: C. fissa, C. ridgewayana, and C. armena.

Cistanche fissa, originally described from around Baku on the Caspian coast of $\mathrm{E}$ Azerbaijan (Meyer 1831), appears to have been first recorded for the Erevan region in Armenia by Grossgejm (1934). It was described and illustrated from there by Tahtadžjan \& Fedorov (1945, 1946 [the illustration, pl. 142, is reproduced in Caturjan 1987 as pl. 155]), who mention species of Chenopodiaceae, Tanacetum, and Artemisia as host plants. It was since recorded from Nahičevan (Cvelev in Karjagin 1957) and from the Kiziki region in south-easternmost Georgia (Mchvetadze 1999). Outside of Transcaucasia its known range extends eastward to Turkmenistan, Iran, and Afghanistan (Novopokrovskij 1958; Schiman-Czeika 1964; Gilli 1979).

Cistanche fissa is a well characterised species, which has been considered by Beck $(1890,1895)$ to represent a section of its own, first named $C$. sect. Heterocalyx Beck then 


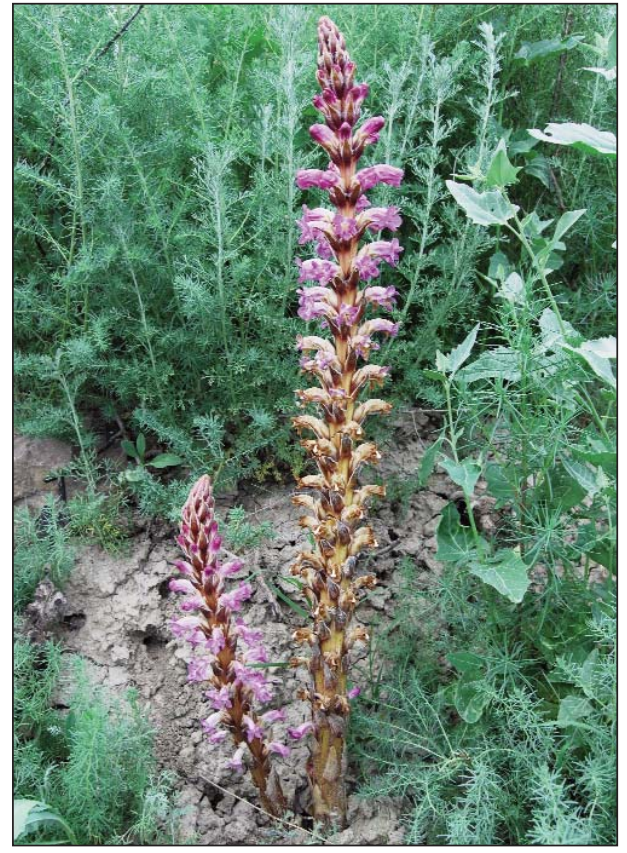

Fig. 2. Cistanche armena, flowering shoots seen near the Hor-Virap Monastery, Armenia. Photograph by the author.

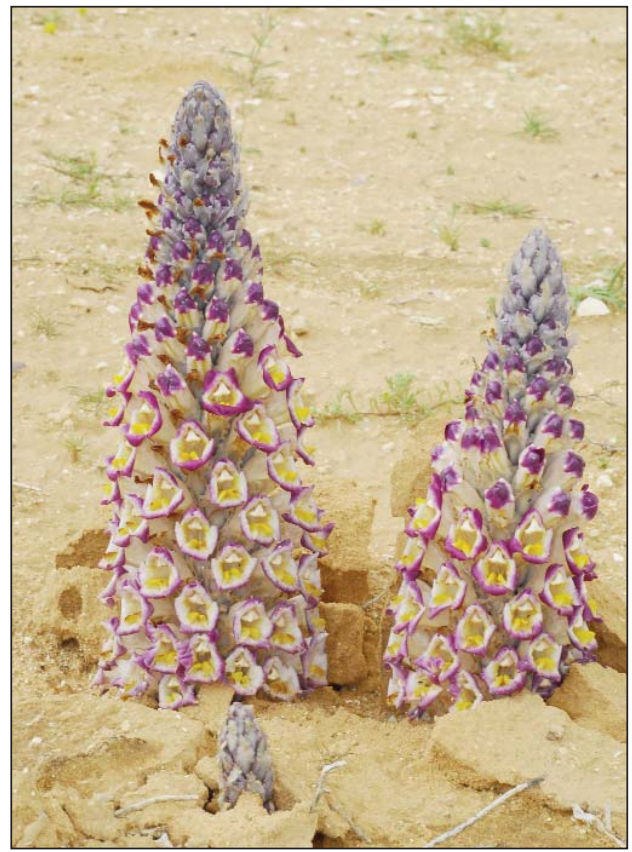

Fig. 3. Cistanche salsa, at Shunra Sands, Western Negev Desert, S Israel. - Photograph by O. Fragman-Sapir.

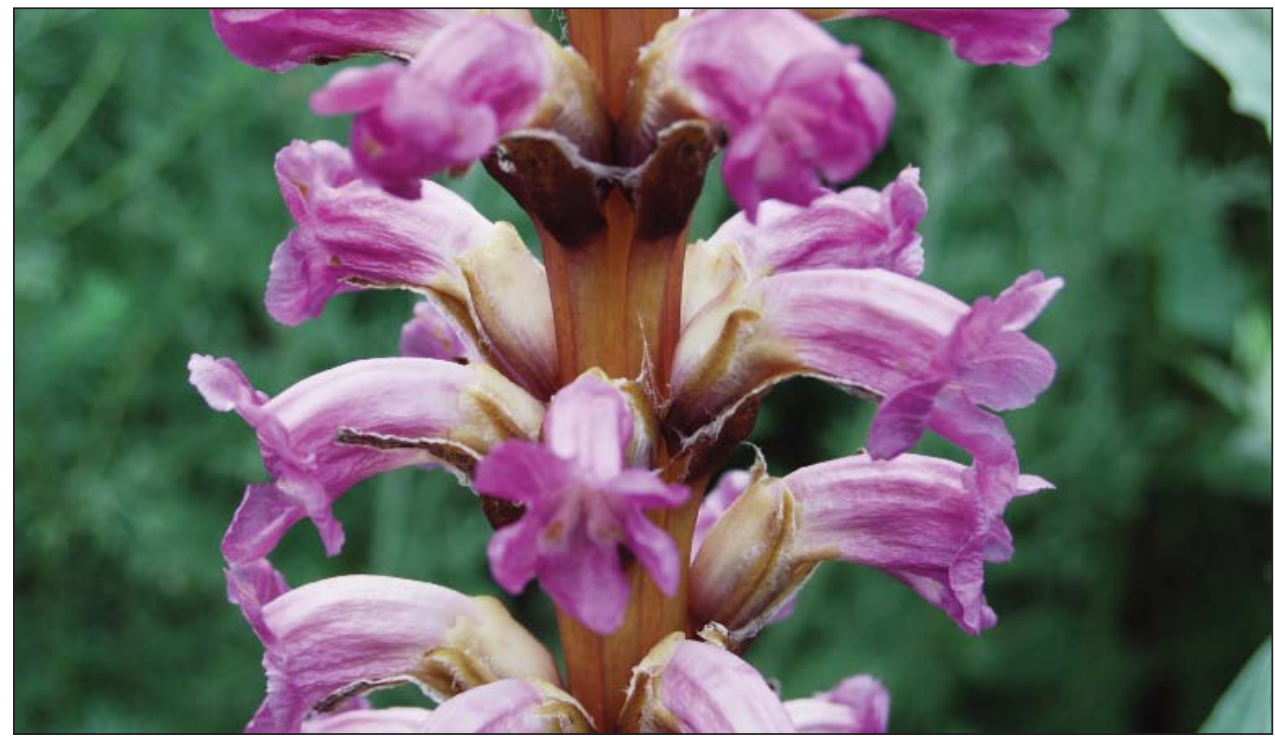

Fig. 4. Cistanche armena, same locality as Fig. 2: part of inflorescence, showing the ribbed stem. Photograph by the author. 
C. sect. Cistanchopsis Beck. It is the only species of the genus with dimorphic calyx segments: the two abaxial ones are wide and rounded; the two lateral ones vary in shape and are usually narrower and \pm acute; and the adaxial one is much reduced in size, linear to subulate, separated from the remainder by deep incisions, or it may be lacking altogether and be replaced by a deep dorsal cleft (the latter condition is the one used by Beck to characterise his section, whereas Meyer's (1831) original description refers only to the former). The inflorescence is dense, cylindrical, \pm woolly, and the corolla is described as white with a bluish-violet limb, or sometimes entirely white (Beck 1930), drying brownish or pale yellow (Cvelev in Karjagin 1957). The shape of the corolla limb is depicted as clearly zygomorphic in Tahtadžjan \& Fedorov's (1946) drawing, a feature that is not confirmed in literature and deserves further study, preferably of live plants.

Cistanche ridgewayana is a new record for the whole of Transcaucasia, even though two of the three specimens at hand had been correctly identified, by Caturjan, on the original labels. These finds were never published, perhaps due to the fact that one specimen of the same gathering was misidentified as $C$. ambigua by the specialist Cvelev. The occurrence of $C$. ridgewayana in our area is not, however, surprising, as the species is known from W Iran close to the border of Azerbaijan (Gilli 1979). From these westerly outposts, C. ridgewayana ranges eastward to Afghanistan, from where it was described, and Middle Asia (Pamir-Alay). Tamarix species are generally cited as the host (e.g., Novopokrovskij 1958; Schiman-Czeika 1964; Saeidi Mehrvarz \& Shahi Shavvon 2008).

Same as Cistanche fissa, C. ridgewayana is a taxonomically very distinctive species that was placed in a section of its own: $C$. sect. Cistanchiella Beck (1930), defined by the lack of bracteoles supporting the calyx. This is not, however, as absolute a difference as one might hope, as occasional flowers with - often small or partly reduced - bracteoles can often be observed among normal, ebracteolate ones. Beck himself must obviously have been aware of these exceptions, as his parenthetical comment "[bracteolae] rarissime minimae inexplicatae?" suggests. $C$. ridgewayana may therefore be more closely akin to C. salsa than is commonly thought, even though it is easily recognised, even in the dry state, by its characteristic habit.

The area of Cistanche armena appears at present to be confined to southern Transcaucasia (but see comments below). The known or presumed host plants are chenopodiaceous shrubs (Halostachys belangeriana, Salsola dendroides) as well as Limonium meyeri. Should the latter host be confirmed, this would be the first instance of Cistanche parasitising a representative of Plumbaginaceae.

As mentioned initially, three more Cistanche species are cited from Transcaucasia in the literature, which are in all likelihood absent from the study area.

Cistanche flava is basically a Middle Asian species, extending to Eastern Azerbaijan (from where it was described) and Iran (Novopokrovskij 1958; Schiman-Czeika 1964; Saeidi Mehrvarz \& Shahi Shavvon 2008). It is the only Transcaucasian species that is yellow-flowered, and the only one that is completely glabrous. It does not seem to present problems as to its taxonomy or chorology.

Cistanche ambigua is a different matter. It was initially described from the Kizil-Kum desert in Middle Asia, but no original material is known to exist. The name has been variously interpreted, as akin to and doubtfully distinct from C. fissa by Beck (1930) or as the accepted name for the species formerly known as C. eremodoxa Bornm. (Gilli 1979). Without revising representative material, it is not possible to be certain which species the 
authors (Cvelev in Karjagin 1957; Caturjan 1987) recording C. ambigua for Transcaucasia had actually in mind. The former cites a single, concrete specimen from near the sovhoz Bejuk-Diuz, collected in 1933 by Gejdeman, which I did not see; the latter mentions one of our localities of both $C$. armena and $C$. fissa, Arazdajan; but she may also have been influenced, in her interpretation of C. ambigua, by Cvelev's misidentification of $C$. ridgewayana as that species. However this may be, I consider it as highly unlikely that $C$. ambigua in its currently accepted sense exists in Transcaucasia.

Finally, the occurrence and - should it be confirmed - exact distribution in Transcaucasia of Cistanche salsa is an open question. Outside our area of study, that species has been recorded from SE Georgia (Kiziki and Gardabani regions) by Mchvetadze (1999) and some parts of Azerbaijan (lowland between Kura and Arax rivers, Kobystan, Nahičevan plain) by Cvelev (in Karjagin 1957). Some or all of these records may be accurate, but they may equally well refer to $C$. armena. The fact that Flora Gruzii, under $C$. salsa, explicitly refers to the Flora Armenii illustration, which in fact represents C. arme$n a$, may or may not be relevant. A further source of wonder is the fact that for the whole of Anatolia only C. salsa has so far been recorded (Gilli 1982). Indeed, Koch's classical locality in the Arax valley is mentioned there as lying in the Turkish province of Kars (which is not impossible, but far from certain). Turkish botanists are therefore encouraged to explore whether $C$. armena, or indeed any or all of the three species growing just outside their national border, might not occur in Turkey, too.

\section{Acknowledgements}

I am grateful to the Tree Project Foundation for financial support. My special gratitude to Ori Fragman-Sapir who provided several high-quality images of Cistanche salsa and gave permission to publish one of them. H. Kazaryan and G. Fajvush I thank for their help in locating Cistanche arme$n a$, and J. Akopyan for identification of the Chenopodiaceae hosts. I wish to express my gratitude to W. Greuter for approving the text and to E. Gabrielian for her constant encouragement to proceed with my botanical work.

\section{References}

Beck-Mannagetta, G. 1890: Monographie der Gattung Orobanche. - Cassel.

- 1895: Orobanchaceae. - Pp. 123-132 in: Engler, A. \& Prantl, K. (ed.) Die natürlichen Pflanzenfamilien, IV.3b. - Leipzig.

— 1930: IV. 261 Orobanchaceae. - In: Engler A.(ed.), Das Pflanzenreich, regni vegetabilis conspectus, 96. - Leipzig.

Boissier, E. 1879: Flora orientalis, sive enumeratio plantarum in Oriente a Graecia et Aegypto ad Indiae fines hucusque observatarum, 4. - Genève \& Basel, Lyon.

Caturjan T. G. 1987: Sem. 4. Orobanchaceae Lindl. - Zarazihovye. - Pp. 361-384 in: Tahtadžjan, A. L. (ed.), Flora Armenii, 8. - Erevan.

Domina, G. \& Raab-Straube, E. von, 2010: Orobanchaceae. - In: Raab-Straube, E. von (ed.), Euro+Med Plantbase - the information resource for Euro-Mediterranean plant diversity (http://ww2.bgbm.org/EuroPlusMed/PTaxonDetail.asp?NameCache=Orobanchaceae\&PTRef $\underline{\mathrm{Fk}=7500000)}$ [consulted October 2013].

Gilli, A. 1979: Die Orobanchaceen der "Flora Iranica". - Candollea 34: 279-305. 
- 1982: 90. Orobanchaceae. - Pp. 1-23 in: Davis, P. H. (ed.), Flora of Turkey and the East Aegean Islands, 7. - Edinburgh.

Greuter, W., Burdet, H. M. \& Long, G. 1989: Med-Checklist, 4. - Genève \& Berlin.

Grossgejm, A. A. 1934: Flora Kavkaza, 4. - Baku.

- 1949: Opredelitel' rastenii Kavkaza. - Moskva.

Koch, K. 1843: Catalogus plantarum, quas in itinere per Caucasum, Georgiam Armeniamque ann. MDCCCXXXVI et MDCCCXXXVII collegit (continuatio). - Linnaea 17: 273-314.

Karjagin, I. I. (ed.) 1957: Flora Azerbajdžana, 7. - Baku.

Meyer, C. A. 1831: Verzeichniss der Pflanzen, welche während der in den Jahren 1829 und 1830 unternommenen Reise im Caucasus und in den Provinzen am westlichen Ufer des Caspischen Meeres gefunden und eingesammelt worden sind. - St. Petersburg.

Mchvetadze, D. I. 1999: 132 Orobanchaceae Vent. - Pp. 232-273 in: Kutateladze, Š. I. (ed.), Flora Gruzii, ed. 2, 12. - Tbilisi [in Grusinian].

Novopokrovskij, I. V. 1958: Sem. CXLVI. Zarazihovye - Orobanchaceae Lindl. - Pp. 19-117 in: Komarov, V. L. (ed.), Flora SSSR, 23. - Leningrad.

Saeidi Mehrvarz, M. \& Shahi Shavvon, R. 2008: Notes on the genus Cistanche (Orobanchaceae) in Iran. - Iran. J. Bot. 14: 95-99.

Schiman-Czeika, H. 1964: Orobanchaceae. - In: Rechinger, K. H. (ed.) Flora iranica, 5. - Graz.

Tahtadžjan, A. L. \& Fedorov, A. A. 1945: Flora Erevana. Opredelitel' rastenij okrestnostej Erevana. Erevan [in Armenian].

— \& - 1946: Atlas risunkov k "Flore Erevana". - Erevan [in Armenian].

— \& - 1972: Flora Erevana. Opredelitel’ dikorastuščih rastenij Araratskoj kotloviny. - Leningrad.

Address of the author:

Mariam V. Aghababyan,

Rue Lagorsse 29, F-77300 Fontainebleau, France.

E-mail: m_agababian@hotmail.com 
